\section{Review Design Perencanaan Gedung Convention Hall Putri Karang Melenu Kabupaten Kutai Kartanegara Provinsi Kalimantan Timur}

\author{
Tumingan ${ }^{1}$ Darmansyah Tjitradi ${ }^{2}$ \\ 1 Program Studi Teknik Sipil, Politeknik Negeri Samarinda \\ 2 Program Studi Pendidikan Profesi Insinyur, Universitas \\ Lambung Mangkurat \\ $\bowtie \quad$ tumingan@polnes.ac.id
}

\section{Pendahuluan}

Kota Tenggarong merupakan Ibukota dari Kabupaten Kutai sebelum terjadi pemekaran daerah pada tahun 1999 menjadi 3 Kabupaten dan 1 Kota yakni Kabupaten Kutai, Kabupaten Kutai Timur, Kabupaten Kutai Barat dan Kota Bontang. Setelah pemekaran Kabupaten Kutai diganti dengan nama Kabupaten Kutai Kartanegera untuk menbedakan Kabupaten sebelum pemekaran dan Kabupaten setelah pemekaran daerah (Wikipedia).

Untuk menunjang sarana prasarana Kabupaten Kutai Kartanegara sebagai Kabupaten tertua tentu berbenah dengan membangun sarana prasarana infrastruktur contohnya bangunan Gedung yang nantinya akan digunakan berbagai kegiatan Bersama atau convention hall. Pada saat awal perencanaan, akan dibangun Gedung serba guna dua lantai dengan fungsi lantai satu untuk secretariat, ruang pertemuan kecil dan lain-lain. Sedangkan di lantai dua akan digunakan sebagai ruang pertemuan. Konsep perencanaan awal pada lantai satu banyak menggunakan kolom dengan modul/fasad jarak kolom 7,2 meter. Untuk lantai dua direncanakan tanpa kolom bagian tengah dan langsung ditutup dengan atap menggunakan struktur atap konstruksi Baja. Proses perencanaan sudah selesai dan diserahkan kepada Dinas Pekerjaan Umum sebagai Pihak yang membiaya perencanaan Gedung tersebut.

Proses pengadaan barang/jasa konstruksi telah dilewati sesuai prosedur dan peraturan yang ada yakni melalui proses tender/lelang pekerjaan konstruksi dan telah ditetapkan salah satu Perusahaan berdasarkan proses pengadaan/lelang. Karena bangunan Gedung tersebut akan digunakan sebagai Gedung serba guna, untuk pertemuan berskala besar di tingkat Kabupaten Kutai, pihak Pemerintah setempat dalam hal ini Bupati Kutai melakukan ground breaking pada awal
Tulisan ini merupakan hasil analisis dalam mengevaluasi ulang perhitungan kapasitas struktur Gedung convention hall Putri Karang Melenu Tenggarong terhadap hasil perencanaan awal akibat adanya pengurangan kolom bagian tengah gedung untuk memperluas ruangan memenuhi fungsi ruang pertemuan. Evaluasi dilakukan menggunakan bantuan software Struktur Analisis Program (SAP) dan pengecekan lapangan terhadap lendutan yang terjadi. Dari hasil evaluasi analisis diperoleh penggunaan material lebih sedikit/ekonomis, sedangkan pengamatan lendutan diperoleh hasil lebih kecil dari lendutan hasil analisis khusus akibat beban permanen atau beban mati. Kondisi ruangan menjadi luas dan lapang tanpa kolom di bagian tengah ruangan.

Kata kunci: Redesign, Bangunan Gedung, Convention Hall, SAP

Diajukan: 10 Juni 2020

Direvisi: 28 September 2020

Diterima: 14 Maret 2021

Dipublikasikan online: 15 Maret 2021

pembangunan. Setelah prosesi ground breaking, rombongan Bupati Kutai Kartanegara meninjau gambar perencanaan yang sudah disiapkan team proyek. Setelah memperoleh penjelasan konsep perencanaan dari Kepala Dinas Pekerjaan Umum, Bupati Kutai Kartanegara menyampaikan pemikirannya bahwa ruangan yang akan dibangun merasa sempit karena terdapat kolom-kolom pada bagian dalam ruangan, sehingga Bupati Kutai menyarankan agar konsep perencanaan awal yang dilakukan PT. Anex Kumara Surabaya minta dirubah yang semula dalam ruangan terdapat kolom-kolom menjadi ruang terbuka baik pada lantai satu maupun lantai dua, dengan menghilangkan struktur kolom pada bagian tengah Gedung tersebut.

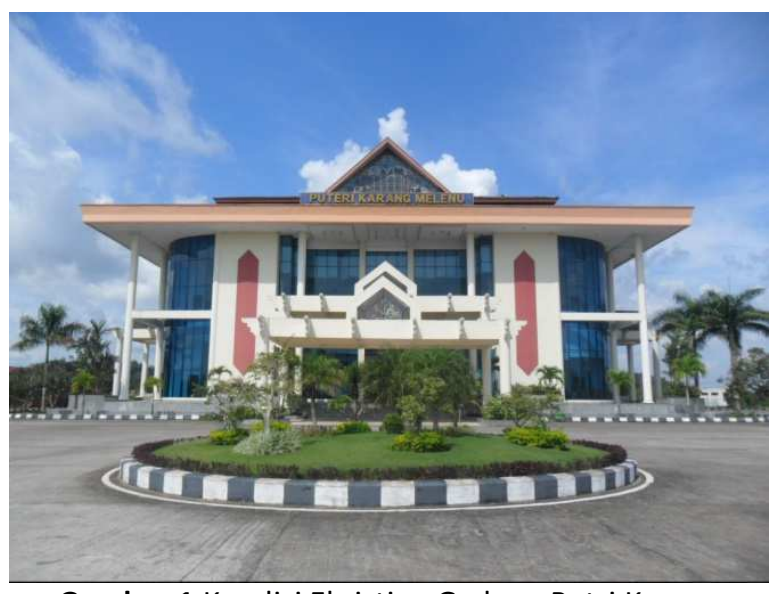

Gambar 1 Kondisi Eksisting Gedung Putri Karang Melenu Tenggarong.

Gambar 1 adalah kondisi eksisting saat ini Gedung Serba Guna/Convention Hall Putri Karang Melenu di

Cara mensitasi artikel ini:

Tumingan dan Tjitradi, D (2020) Review Design Perencanaan Gedung Convention Hall Putri Karang Melenu Kabupaten Kutai Kartanegara Provinsi Kalimantan Timur. Buletin Profesi Insinyur 4(1) 018-022 
Desa Teluk Dalam Kecamatan Tenggarong Seberang, Kabupaten Kutai Kartanegara (PT. Anex kumara, 1996).

Lokasi gedung serbaguna Putri Karang Melenu sangat strategis, berada di seberang Gedung Kantor Bupati Kutai Kartanegara dan Perkantoran-perkantoran Pemerintah Daerah Kabupaten Kutai Kartanegara. Di sekelilingnya terdapat Rumah Sakit Umum A.M. Parikesit, Sekolah Menengah Tingkat Atas Unggulan, Stadion, rencana kampus Institut Seni Budaya Indonesia (ISBI) Kabupaten Kutai Kartanegara dan lain-lain.

Untuk mempermudah dan mempercepat proses perhitungan struktur utama Gedung serbaguna, menggunakan bantuan software Structure Analysis Program/SAP 2000 yang sudah ada dan umum digunakan pada tahun 1996 (Wiryanto, 2013).

\section{Metode}

Atas saran dan masukan Bupati Kutai tersebut dilanjutkan dengan melakukan diskusi beberapa orang diantaranya Kepala Dinas Pekerjaan Umum Kabupaten Kutai, Pejabat Pembuat Komitmen atau Pimpinan Proyek (saat itu), Team Teknis Dinas, Konsultan Pengawas dan Kontraktor Pelaksana diperoleh keputusan mengikuti saran dan usulan Bupati Kutai Kartanegara dengan menghilangkan 12 kolom pada lantai bawah dengan modul/ fasad antara kolom tetap berjarak 7,2 mater sehingga mendapatkan ruang terbuka tanpa kolom dengan ukuran 28,8 meter $\times 36,0$ meter dengan modul $4 \times 7,2$ meter dan $5 \times 7,2$ meter (PT. Bahtera Bahagia Kontraktor, 1996).

Kesepakatan hasil diskusi pembahasan perubahan perencanaan yakni menghilangkan sebanyak 12 kolom pada bagian dalam/tengah ruangan. Posisi kolom yang mengalami perubahan atau redesign adalah kolom pada As F sampai As I dan As 3 sampai As 5 seperti ditunjukkan pada Gambar 2.

Sebenarnya dengan menghilangkan kolom bagian tengah Gedung, dengan sendirinya juga merubah struktur rangka atapnya. Tetapi dalam pembahasan ini tidak dibahas prosedur perubahan rangka baja atap yang pada perencanaan awal, rangka atap ditumpu kolom dengan jarak 7,2 meter berubah menjadi struktur atap profil dengan bentang 28,8 meter.

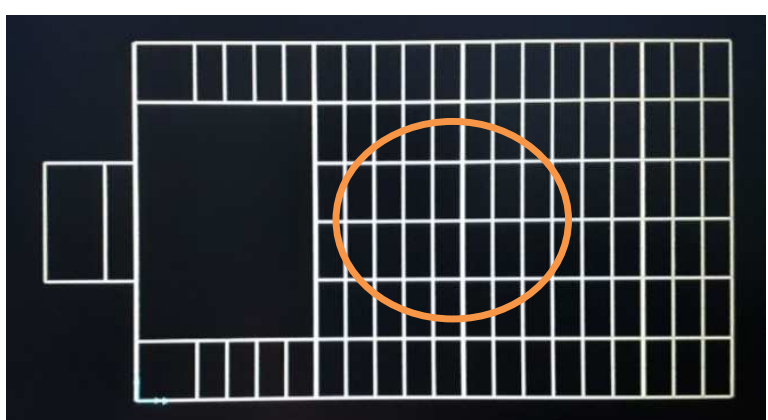

Gambar 2 Denah posisi Struktur kolom yang di hilangkan

Seperti pada umumnya, perhitungan struktur gedung menggunakan bantuan software SAP 2000, dimulai dengan membuat grid atau garis bantuan koordinat tiga arah (3D), menentukan koordinat masing-masing arah, membuat frame (balok, kolom, sloof, ring balk), membuat dimensi/penampang untuk frame, menentukan dimensi dari frame yang dipilih, memasukkan beban-beban (beban mati, beban hidup/guna, beban angin, beban gempa, beban lainnya sesuai kebutuhannya), menentukan kombinasi pembebanan yang digunakan, memilih/menentukan tipe pembebanan (terpusat, Garis merata, trapezium atau merata pada pelat) (SNI 1727:2013, SNI 1726:2012)

Setelah yakin semua input dalam SAP 2000 benar dengan melakukan pengecekan terlebih dahulu, bisa dilanjutkan dengan memproses perhitungan (running).

Selesai running, dapat dilanjutkan dengan pengecekan masing-masing frame terhadap kapasitas yang diinginkan, misalnya kapasitas terhadap penampang atau kapasitas bahan dengan mengecek keseimbangan gaya-gaya luar yang terjadi (biasanya bidang momen, bidang gaya lintang, bidang gaya geser) serta kemungkinan-kemungkinan yang lainnya.

Untuk pengendalian kualitas struktur utama pada Gedung serbaguna/convention hall ini selain kemampuan dari analisis struktur, dalam pelaksanaan perlu dilakukan pengendalian kualitas yang benar dan harus dilakukan pengukuran terhadap besarnya penurunan yang terjadi, khususnya besaran penurunan akibat berat sendiri struktur untuk memudahkan pelaksanaan. Apabila harus dibebani keseluruhan, untuk memberikan beban hidup atau beban guna waktunya tidak cukup (CV. Patria Paramita Konsultan, 1996).

\section{Hasil Kerja}

\section{Perubahan Jarak Balok}

Kegiatan convention \& exhibition adalah kegiatan yang diikuti sekelompok orang yang akan menyelenggarakan atau mengikuti kegiatan pertemuan, pertunjukkan, pameran, promosi baik secara bersamaan ataupun terpisah. Kegiatan di gedung serbaguna meliputi, kegiatan konvensi (pertemuan skala besar maupun sedang berupa seminar, meeting, conference, pertunjukkan), dan kegiatan ekshibisi (pameran, promosi maupun louncing suatu produk).

Memperhatikan fungsi dari convention hall dan hasil kesepakatan setelah beberapa kali dilaksanakan diskusi team proyek, pemilihan/penetapan untuk membuat ruangan menjadi lapang dan terbuka adalah suatu keharusan yang dipenuhi.

Sebelum menetapkan struktur kolom yang akan dihilangkan, semua pihak harus memahami terlebih dulu pola struktur utama gedung hasil perencanaan. Dengan menginputkan data-data konstruksi, diperoleh hasil pola struktur utama seperti ditunjukkan pada Gambar 3, yakni perspektif pola struktur utama hasil perencanaan awal, dimana jarak antara kolom sampai kolom dengan jarak/modul 7,2 meter dengan pola pelat lantai ukuran 3,6 7,2 meter.

Proses pembahasan team proyek untuk mencari dan mengevauasi serta kemungkinan-kemungkinan yang akan terjadi, sepakat mengambil putusan dengan menghilangkan 12 buah kolom pada bagian tengah 
Gedung serbaguna/convention hall. Apabila kita tinjau potongan bangunan yang menunjukkan posisi kolom yang dibahas dapat dilihat pada Gambar 4, perspektif potongan struktur utama dengan mengambil As F - I dan As 3-5 dengan alasan untuk kenyamanan sirkulasi pendatang, begitu masuk gedung akan terlihat suasana terbuka dengan elevasi yang tinggi karena tidak ada lantai 2. Area tersebut juga dapat dimanfaatkan sebagai area transit sementara sebelum melakukan kegiatan, juga bisa dimanfaatkan untuk area her-registrasi apabila memerlukan tahapan registrasi ulang.

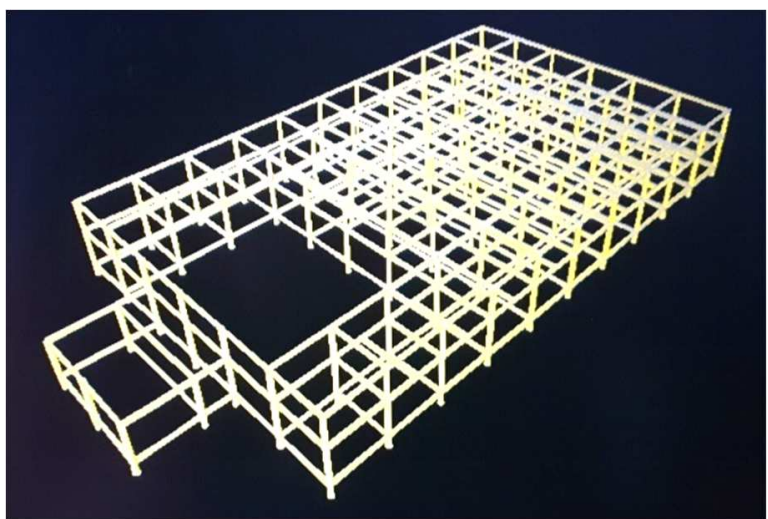

Gambar 3 Perspektif Struktur Utama Perencanaan

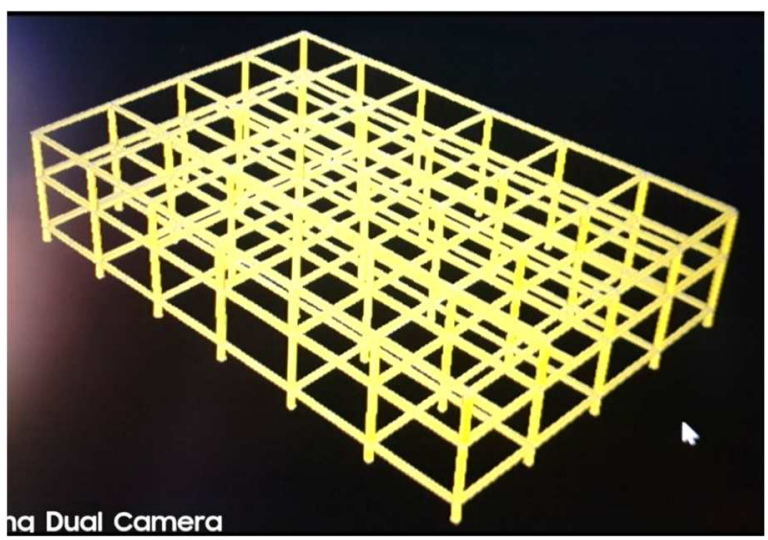

Gambar 4 Perspektif Struktur Utama pada As tinjauan sebelum Redesign

Area terbuka transit dibatasi dengan dinding massif dengan pintu yang lebar untuk akses masuk ke ruangan serbaguna/convention hall nya. Ruang convention hall ini yang juga memerlukan ruangan bebas dan luas tetapi dengan ketinggian terbatas karena terdapat lantai 2 . Pada ruangan inilah sejumlah kolom yang dihilangkan baik kolom pada lantai 1 dan kolom pada lantai 2. Dalam tampilan format SAP seperti ditunjukkan pada Gambar 5 , perspektif struktur utama pembalokan lantai 2 dengan tanpa kolom sebanyak 12 kolom pada As F-I dan As 3-5.

Metode redesign yang dilakukan dengan cara beberapa kali mencoba perubahan jarak balok, dimensi balok (trial error) yang berdampak pada ukuran pelat lantai dalam program analisis menggunakan software struktur analisis SAP2000, nilai pembebanan tetap karena fungsi gedung juga tetap.

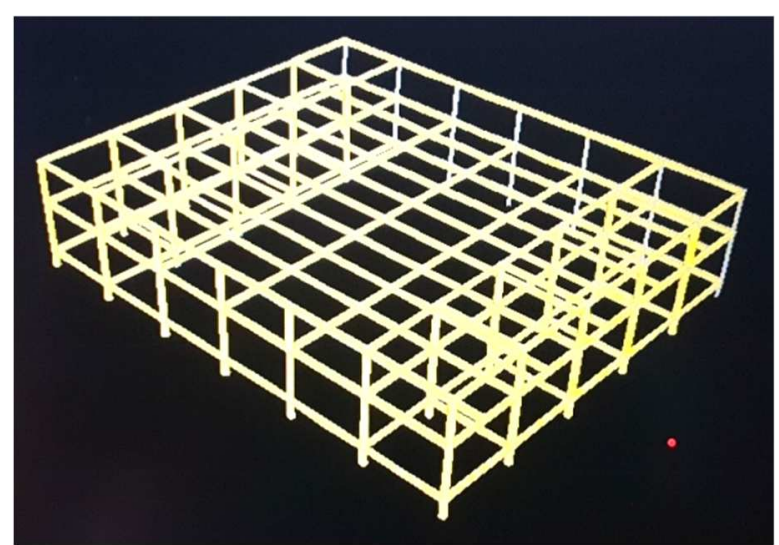

Gambar 5 Perspektif Struktur Utama pada As tinjauan setelah Redesign

Berbagai pertimbangan, muncul beberapa alternative diantaranya dengan merubah jarak balok menjadi lebih rapat dalam dua arah (arah X dan arah Y). Beberapa kali percobaan diperoleh hasil tidak efisien yakni balok Induk jauh lebih besar dengan dimensi percobaan yang aman $60 \times 125 \mathrm{~cm}$.

Dicoba Kembali, mengambil inspirasi dengan sistem/konsep pembalokan pada jembatan yakni dengan mengambil perubahan jarak satu arah saja (dalam perhitungan ini mengambil jarak arah $X$ diperkecil sedangkan jarak arah $Y$ tetap dengan asumsi sebagai balok pengikat atau bracing).

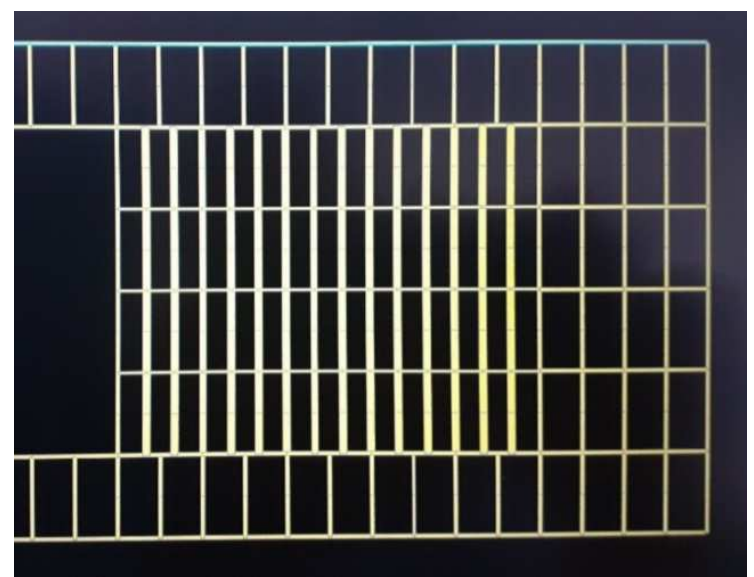

Gambar 6 Pola Struktur Utama hasil redesign

Hasil terakhir yang dipilih dari beberapa kali percobaan adalah konsep balok jembatan yakni menggunakan balok utama seperti gelagar jembatan satu arah yakni bentang pendek dengan jarak percobaan terakhir sejauh 2,4 meter memerlukan penampang balok $60 \times 105 \mathrm{~cm}$, balok arah sisi panjang menjadi balok bracing untuk penahan momen torsi/momen punter dengan dimensi $20 \times 60 \mathrm{~cm}$ jarrah 7,2 meter. 
Dimensi pelat lantai juga menjadi lebih kecil bahkan berubah dari pelat dua arah menjadi pelat satu arah karena perbandingan sisi Panjang terhadap sisi pendek Ly/Lx $\geq 3,0$ sehingga penulangan pelat lantai juga menjadi berkurang.

\section{Hasil Perhitungan}

Beberapa keuntungan hasil perhitungan ulang dimensi balok setelah menghilangkan 12 kolom bagian tengah gedung serbaguna/convention hall Putri Karang Melenu diantaranya :

1. Total volume beton struktur utama, sebelum perubahan dengan setelah perubahan menjadi berkurang atau lebih kecil.

2. Total volume baja beton tulangan juga berkurang cukup besar, berdasarkan hitungan hamper mencapai $30 \%$.

3. Metode pelaksanaan struktur beton sebenarnya sama tetapi perlu pengawasan lebih ketat/serius, khususnya pada saat pembongkaran begesting setelah umur beton memenuhi persyaratan.

4. Tambahan pekerjaan khusus untuk pekerjaan ini adalah control lendutan yang terjadi. Pekerjaan ini diwajibkan untuk memantau kapasitas struktur dari sisi lendutannya.

Berdasarkan SNI 2847:2013 Tabel 9.5(b) lendutan izin maksimum untuk lantai (tidak ada lendutan balok) yang menahan atau berhubungan struktur lain yang mungkin tidak rusak akibat lendutan dengan nilai maksimum sebesar I/240 atau sebesar $120 \mathrm{~mm}$, dari hasil perhitungan SAP 2000 untuk beban mati saja diperoleh lendutan $32 \mathrm{~mm}$, sedangkan hasil pengukuran lapangan pada saat pembongkaran begesting diperoleh lendutan 21 mm maka struktur balok, aman.

Terhadap luasan ruangan hasil redesign membuat ruangan menjadi lapang dan terbuka karena tidak ada kolom yang terpasang di tengah ruangan. Kondisi setelah redesign seperti terlihat pada Gambar 7.

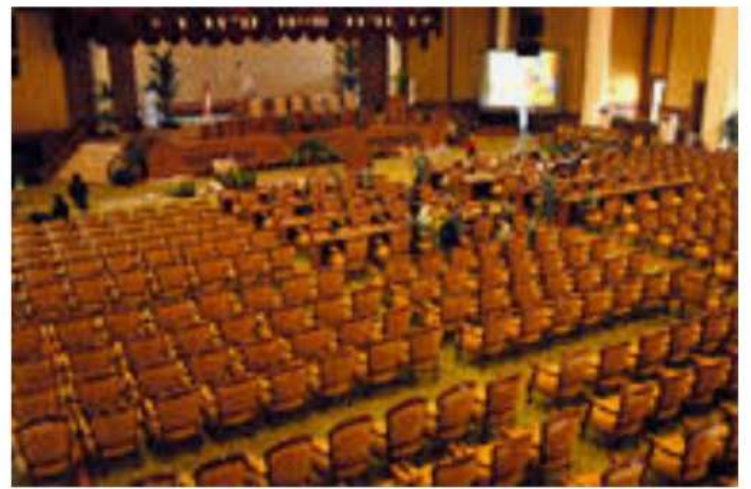

Gambar 7 Kondisi ruangan convention hall setelah redesign (saat ini)
Untuk memastikan bahwa kapasitas struktur memenuhi unsur keamanan secara analisis maupun hasil pengukuran lapangan, juga perlu dilakukan pengendalian kualitas hasil pengerjaan.

Pengendalian kualitas dimulai dari persiapan rencana penggunaan material baik beton maupun baja tulangan. Untuk mutu beton diawali dengan membuat rancangan campuran beton yang akan digunakan dengan mengambil material yang benar-benar nantinya akan digunakan. Apabila material untuk trial mix mengalami perubahan/penggantian, trial mix harus diulang kembali sehingga diperoleh komposisi bahan yang sesuai, harapan mutu yang diinginkan sangat mudah dicapai. Pengujian baja tulangan dilakukan dengan pengujian tarik, untuk memastikan mutu baja tulangan sesuai dengan yang direncanakan dari awal dengan batasan hasil kuat tarik leleh dan kuat Tarik maksimumnya (Jack C. McCormac, 2001).

Hasil pengendalian mutu di lapangan, tidak cukup membuat benda uji lapangan berbentuk kubus/silinder tetapi juga dilakukan pengujian lapangan dengan alat hammer test secara berkala. Semua dokumen pengendalian mutu disusun rapi dan teratur sesuai Jenis dan jadwal pelaksanaan pengujian yang dilakukan.

\section{Kesimpulan}

Berdasarkan hasil analisis struktur menggunakan software SAP 2000 dan pemantauan lapangan terhadap parameter yang ditentukan dapat disimpulkan bahwa:

1. Hasil redesign struktur utama pembangunan Gedung Convention Hall Putri Karang Melenu Tenggarong Kabupaten Kutai, menggunakan material lebih hemat untuk bahan beton dan bahan baja tulangan.

2. Terhadap keamanan lendutan, jauh dibawah batas aman teoritis untuk pembebanan berat sendiri yakni $21 \mathrm{~mm}<32 \mathrm{~mm}$ untuk beban mati saja.

3. Kondisi ruangan menjadi semakin luas dan lapang karena terbuka, tidak ada kolom dalam ruangan.

\section{Ucapan Terimakasih}

Ucapan terimakasih kami tujukan kepada teman-teman yang membantu mencarikan dokumen dan turut berperan pada saat pelaksanaan pembangunan. Juga kepada PT. Bahtera Bahagia Kontraktor Samarinda yang menyediakan bantuan data.

\section{Referensi}

CV. Patria Paramita Konsultan (1996) Jln Ir. H Juanda Komplek Wijaya Kusuma VIII Samarinda, Konsultan Pengawas pembangunan Gedung Serba Guna/ Convention Hall Putri Karang Melenu Tenggarong Kabupaten Kutai. 
https://id.wikipedia.org/wiki/Kabupaten_Kutai_Kartane gara download 6 Juni 2020.

Jack C. McCormac (2001) Design of Reinforced Concrete + Software CONCAD.

PT. Anex kumara (1996) JIn Klampis Semolo Timur No 10 Surabaya, Konsultan Perencana Gedung Serba Guna / Convention Hall Putri Karang Melenu Tenggarong Kabupaten Kutai.

PT. Bahtera Bahagia Kontraktor (1996) Jln Dr. Sutomo Samarinda, Pelaksana pembangunan Gedung Serba
Guna / Convention Hall Putri Karang Melenu Tenggarong Kabupaten Kutai.

SNI 1726:2012. Tata Cara Perencanaan Ketahanan Gempa Untuk Struktur Bangunan Gedung dan Non Gedung, BSN.

SNI 2847:2013. Tata Cara Perhitungan Struktur Beton untuk Bangunan Gedung. Bandung.

SNI 1727:2013. Beban Minimum Untuk Perancangan Bangunan Gedung dan Struktur Lain., BSN.

Wiryanto (2013) Komputer Rekayasa Struktur dengan SAP2000. 